$\begin{gathered}\text { Journal of Business Management and } \\ \text { Economic Research }\end{gathered}$
$\begin{gathered}\text { 2019,3 (10): 1-19 DOI: } 10.29226 / T R 1001.2019 .159 \\ \text { Journal Homepage: https://www.jobmer.org }\end{gathered}$

\title{
Effect of Service Quality on Customer Loyalty in Selected African Airlines
}

\author{
Lukas Maina Njeru \\ PhD student, Department of Management Science, School of Business and Economics \\ patohngene@gmail.com
}

Prof. Thomas K. Cheruiyot

Department of Marketing Management, School of Business and Economics, Moi University

\section{Prof. Loice Maru}

Department of Marketing Management, School of Business and Economics, Moi University

\begin{abstract}
The purpose of this paper was to determine effect of service quality and customer loyalty in selected African airlines. The study was informed by Expectation Disconfirmation theory, Theory of Reasoned Action and Discrepancy Theory. Explanatory survey research design was employed in the study. The study targeted 256,254 customers drawn from 9 Airlines in Africa which included Kenya Airways, Ethiopia Airlines, Egypt Air, Rwandair, South African Airways, Mozambique Airlines, Air Zimbabwe, Air Tanzania and Air Namibia. Stratified and simple random sampling techniques were used to select a sample of 750 customers. This study used questionnaires to collect data relevant to the study. Hypotheses were tested by using Multiple Regression Analysis Model. The study findings showed that tangibility $(\beta=0.140 \mathrm{p}<0.0 \%)$, reliability $(\beta=0.204, \mathrm{p}<0.0 \%)$, responsiveness $(\beta=0.122$, $\mathrm{p}<0.05)$, assurance, $(\beta=0.093, \mathrm{p}<0.05)$ and empathy had significant and positive effect on customer loyalty in airlines industry. This infers that in airline industry service quality is prerequisite for customer loyalty. It is therefore paramount for the airline to ensure there are tangible and reliable services. Moreover, managers need to enact polices which encouraged responsiveness, assurance and empathy in airlines.
\end{abstract}

Keywords: Tangibility, Reliability, Assurance, Responsiveness, Empathy 
Journal of Business Management and Economic Research (JOBMER), vol.3, issue.10, pp.1-19

\section{Introduction}

Customer loyalty is a tendency or behaviour of preferring same firm in purchases (Rizka and Widji, 2015) which has attitudinal and behavioural dimension. This is specifically an exhibition of the attitude and behaviours associated with the customers. The principle of customer loyalty is aptly depicted in the fact that organizations should strive to give focus of their marketing practices and processes on existing customers and struggle to create and maintain positive relationships between them and their customers (Hutt, et al., 2005). This means that the aspect of loyalty becomes a 2-way notion in which the customer's loyalty is in turn rewarded by the company being loyal to this customer through enhanced relationships that make the customer more endeared to the organization. In today's competitive world, companies and organizations tend to place the customers at the centre of their attention, and have identified that their loyalty is the critical to earning a competitive advantage and edge (Molaee, 2013) over other organizations. To this end, consumer loyalty is correlated with factors like service quality, (Topçu \& Uzundumlu, 2010). This clearly highlights the important fact that while the goal is having an enhanced competitive edge for the company, customer loyalty becomes a primary focus for the company which can only be driven through the company giving focus on the quality of the services offered to the customer. On the other hand, this means that customers may prefer firms which ensure similar satisfaction levels through provision of good service quality. Consequently, determination of the factors that influence the relationships between the firm and consumer is necessary in providing a means of gaining an understanding to these situations.

Service quality is critical aspect for the Airline industry. This important aspect has been established as one of the most essential means of establishing and maintaining a healthy, competitive position and improving organizational performance (Ghimire, 2010). Abedin (2015) also notes that service quality is required in the creation of customer satisfaction and it is a concept whose basics are intertwined with customer perceptions and customer expectations. Within the current business disposition, service quality is increasingly becoming not only the rhetoric of virtually every business enterprise, but also a crucial concept in service research and studies. It is fundamentally impossible for a business organization or company to survive without having a firm foundation in which customer satisfaction and brand loyalty are key aspects. 
Journal of Business Management and Economic Research (JOBMER), vol.3, issue.10, pp.1-19

It is thus critical to highlight that research has shown repeatedly that service quality influences organizational outcomes such as performance, superiority, increased sales profit and market share (Kheng et al., 2010), improvement in customer relations, enhancement of the corporate image and promotion of customer loyalty (Qadri\& Khan, 2014; Ehigie, 2006) in addition to providing a means through which the organization or company has the capability and muscle or surviving an increasingly competitive environment. In recent times, the search for quality is debatably the most important consumer trend because consumers are now increasingly demanding higher and better quality in the products and services they are offered more than ever before. This gives a glimpse of a customer base that is increasingly being informed and in turn providing them with more power in terms of determining their level of demand for better services and products. Through this, researchers all over the globe claim that offering quality services to the customer tends to give a viable and ecological competitive advantage to any business hence a direct influence of the very survival of the business.

Most airlines in Africa such as Egypt Air, Rwandair, South African Airways, Mozambique Airlines, Air Zimbabwe, Air Tanzania and Air Namibia are exposed to a heavy and growing competition against giant airline alliances on the international scene, regional alliances in Africa and the Middle East, including the well-established privately owned airlines from Europe, Middle East and Africa. Most airlines have and continuously find it difficult to retain customers. This means that unless these airlines prepare and develop specific strategies to counter the upcoming competitive pressure, the consequences could be regrettable and a number of reasons are behind this growing trend of customer disloyalty.

Research has shown that poor service quality has negatively and significantly influenced customer loyalty in airline industry (Bielen \& Demoulin, 2007). This means that with each decrease in the level of service quality, there is a boomerang negative effect on the level of customer loyalty. Thus, it is critical to ensure that customers are retained in order to ensure the goals of the company are achieved. However, no study has tested key service quality dimensions directly to see if they have a significant influence on customer loyalty in the airline industry in Africa. Thus, this study hypothesized that :

Ho1: There is no significant effect of reliability on customer loyalty in selected African Airlines Ho2: There is no significant effect of empathy on customer loyalty in selected African Airlines 
Journal of Business Management and Economic Research (JOBMER), vol.3, issue.10, pp.1-19

Hоз: There is no significant effect of tangibles on customer loyalty in selected African Airlines Ho4: There is no significant effect of assurance on customer loyalty in selected African Airlines Ho5: There is no significant effect of responsiveness on customer loyalty in selected African airlines

\section{Empirical Reviews}

Research has shown service quality to be a strong predictor of customer loyalty. Various studies have been conducted in the airline industry where the service quality dimension has been tested as predictors of customer satisfaction. Few studies have however investigated the association between each of the service quality dimensions and customer loyalty and have reported some mixed results. In a studyin the hotel industry in Jordon, Al-Rousan and Mohamed (2010) found that empathy, reliability, responsiveness, tangibles and assurance significantly forecast customer loyalty. On the other hand, Liang (2008) conducted a study in the hotel industry in United Stated and found that service quality has a positive influence on consumer loyalty. In addition, Clottey et al. (2008) in their study of the United States retail industry found that there was strong statistical evidence that service quality had a significant influence on customer loyalty. However, these studies were more based on the retail industry which is product-based rather than service-based industry such as airline industry. Similarly, Jamal and Anatassiadou (2007) conducted a study on airline customers in Greece relating to service quality and consumer loyalty. The findings showed that reliability, tangibility and empathy are positively related to consumer loyalty. Chen and Lee (2008 found that service quality has a positive influence on consumer loyalty. In their study on the Greece retailing industry, Gounaris et al. (2003) found out that service quality has significant influence on consumer loyalty. Nevertheless, despite studies associating service quality with consumer loyalty, they were conducted in online shoppers but not in the airline industry. Thus the need to have a specific study on the association between service quality and consumer loyalty in the airline industry in order to better understand whether the relationships found in online shopping are replicable and confirmed in the airline industry.

For instance, Arasli et al., (2005), reported that assurance, reliability, empathy and tangibles dimensions of service quality were predictors of consumer loyalty. Furthermore, they found that tangibles, empathy and responsiveness were significant predictors of customer loyalty. Zhou (2004) 
reported that reliability and assurance were important predictors of consumer satisfaction. However, the findings were more specific on China and other Asian countries and the results could not be generalized into African based airlines due to differences in economic growth and development in the airlines as well as the dynamic and different economic environment which is also different within the different African countries.

Previous research has suggested that the quality of customer's service experience aids them develop positive value perceptions about the service provider. Carrillat et al., (2009) argue that this means that the intellectual evaluation of the different service quality dimensions will lead to a favourable behavioural response from the consumer.

Empathy as a key dimension of service quality has been found to have a significant positive association with customer loyalty. In addition, Ndubisi (2006) points out that customer satisfaction can be accomplished by offering personalized, flexible and adjustable services that suit to the needs and expectations of the customers. This is in line with the findings of other researches that clearly indicate that empathy has a positive influence on customer satisfaction.

Ladhari et al., (2011) concisely explain the idea of tangibles role in the airline sector or industry. Varying behaviours and attitudes of customers demand high service quality to attain their perception of service provided. Service quality has a linear relationship with success and profitability of the business. General Electric for instance has invested heavily in quality service and in return they earn huge profits every year which highlights high performance. General Electric considered both tangible and intangible aspects of service quality to be equally important in the success of organization (Tax \& Brown, 2012) and eventual performance. Environment and culture of different areas serve as a guide for businesses on how to adapt their policies in the global perspective for a particular area so that they are able to shift their strategies and come up with tailor-made innovations that suit the area of operation. They have to make changes in the setup of their outlets and branches in order to fit in the environment. The airline industry mostly follows identical office ambience set-ups and installs similar service equipment all over the globe to maintain a standard and uniformity in the eye of the customer so that they can see a unique sense of identity. However, adapting of strategies according to cultural needs of particular areas up to some extent will make customers feel more comfortable and loyal (Ganguli and Roy, 2011). 
In other critical research, a positive and significant relationship was found between empathy and customer satisfaction (Iglesias and Guillén, 2004). From the findings of another similar research, it was proposed that customers may remain unsatisfied with service quality if a gap is left in terms of the level empathy that they are accorded by the company. In addition, it was also established by AlMarri et al. (2007) that customer satisfaction is significantly influenced by empathy and it makes the customers contended and in the long-run serves as an important predictor in improving the financial performance of the organization.

In their study, Wieseke et al. (2012) established that consumer that were treated emphatically were more loyal even when mistakes are made during service provision. In this regard, empathy creates an emotional relationship with the customer hence providing the customer with a touch of importance and a sense of belonging. This leads to higher customer retention and creation of a new consumer pool hence increasing the consumer base which in turn increases the eventual number of customers that are loyal to the firm. Juneja (2011) also studied the correlation between service quality dimensions and customer satisfaction and found that customer loyalty can be won through empathy. In addition, other research shows that empathy can play a critical role in improvement of service quality, customer loyalty and finally consumer satisfaction. For instance, Karatepe (2011) assessed the influence of the service environment in terms of empathy and reliability on consumer loyalty. The findings showed that empathy worked as a moderator between quality and customer satisfaction. In addition, the findings showed that empathy can change the behaviour of the customer ultimately and in the long-run, the level of their loyalty to a particular firm.

Three important parameters regarding service quality such as reliability, empathy and service quality were found to be positively correlated with customer loyalty (Siddiqui, 2011). In this case, a positive and significant association was found between all the attributes of service quality and customer loyalty with the mediating influence of customer satisfaction in a research in the retail banking sector in Bangladesh. Furthermore, tangibles, responsiveness and reliability were all found to be directly related with customer loyalty in the Telecommunication industry in Ghana in a research study carried out by Idrissu (2011) whose findings were highly consistent with those of Kheng et al. (2010)where empathy had highest positive association while assurance had least association with customer loyalty. 
Journal of Business Management and Economic Research (JOBMER), vol.3, issue.10, pp.1-19

Agyei and Kilika, (2013) carried out a study in the Kenyan mobile telecommunication sector. From the findings, all the indicators of the SERVQUAL model were found to suggest a positive association between service quality and customer loyalty. Among the indicators of the SERVQUAL model, empathy had the highest influence on customer loyalty. The influence of all the parameters of the customer's perceived service quality had a positive influence on customer loyalty except tangibility in a study by Hassan et al. (2013). Furthermore, all the five constructs of the SERVQUAL model were found to be strongly associated with customer loyalty in a study carried out by Poku et al. (2014) in the Telecommunication industry of Ghana.

The weakness of these studies was in deciding the most important dimensions among the five service dimension dependent on the nature of the customer and there are circumstances in which both of them are important and thus service quality has a significant contribution to customer satisfaction. This study will use descriptive analysis to observe the contribution of service quality on customer satisfaction via the SERVQUAL Model

\section{Material and Methods}

Explanatory research design was used in this study. The study targeted 256,254 customers were drawn from 9 Airlines in Africa which includes Kenya Airways, Ethiopia Airlines, Egypt Air, Rwandair, South African Airways, Mozambique Airlines, Air Zimbabwe, Air Tanzania and Air Namibia. From the 9 airline databases, there is a total using these airlines per month which was taken as the study target population. From the target population of 256,254 customers from the nine (9) airlines in Kenya, a random sample of $750+5 \%$ (non-respondent error) $=788$ customers was selected. This study used structured questionnaires to collect data relevant to the study.

\subsection{Measurement of Variables}

In this study, the measurement scales and indicators were adopted from previous studies. These measurements scales have been validated in prior researches, especially in the context of airlines service (Brady et al., 2002; Colgate and Lang, 2001; Cronin Jr., Brady, and Hult, 2000; Jones, Mothersbaugh, and Beatty, 2000). Modifications and translations was made to transform the measurement scale to be readable for the average reader. In general, the respondents were asked to state their agreement or disagreement with the statements stated. Respondents was give their opinion for each statement using a 5-point Likert scale with 1 to indicate "strongly disagree", 2 to indicate 
"disagree", 3 to indicate "a neutral position", 4 to indicate " agree" and 5 to indicate "strongly agree".

\subsubsection{Dependent variable (Customer loyalty)}

The study adopted five items from Cronin et al. (2000) to measure the customer loyalty which include telling positive things about airline, recommending family, friends and relatives, recommending to someone who seeks airline services, intention to continue using the airline

\subsubsection{Independent Variables (Service Quality Dimensions)}

The study independent variables was based on SERVQUAL scale (Parasuraman, Zeithaml, and Berry,) contain five dimensions of service quality namely tangibles, reliability, responsiveness, assurance and empathy.

\section{Data Analysis}

Data analysis method and procedure covers, Kaiser-Meyer-Olkin (KMO) statistics, Test of Sphericity, Factor Analysis, Correlation Coefficient and Hierarchical Regression Model. Descriptive analysis were used to describe the demographic profile of target respondents in frequency and percentage of the sample characteristics in the form of tables and written explanations as well as central tendencies measurement of constructs that included mean and standard deviation. These demographic profiles consist of gender, age, and race, flight experience and frequency. The correlation analysis was used to give correlation coefficients between the four independent variables measured using seven-item likert scales. Moreover, if the p-value of multiple linear regressions is less than 0.05 , then the relationship between the selected independent variables and dependent variable was significant. Thus, the alternative hypothesis should not be rejected. If not, vice versa.

\section{Results and Discussions}

The sample population consisted of customer of airlines. A total of 750 questionnaires were distributed, data was successfully collected from 634 respondents representing a response rate of $84.5 \%$.

\subsection{Sample Characteristics}

The study sought to establish the personal characteristics of the respondents so as to assist the researcher understanding on the findings. Variables included here are age, gender, nationality and years as airline customer. As far as age of respondents is concerned, $14.8 \%$ of the respondents are in 
the range of 36- 40 years, $16.4 \%$ of the respondents are below 25 years, $18.3 \%$ are above 40 years, $20.5 \%$ are in the range of $31-35$ and $30 \%$ are in the range of 26-30 years. Male respondents represented $59.1 \%$, on the other hand $40.8 \%$ were female. As evidenced in Table 1, 53.5\% of them are Africans,23.2\% are Asians,15\% are Europeans and 8.4\% are Australians. The results revealed that $73.2 \%$ of the respondents have been customers with the airline for 1 to 5 years, $18.3 \%$ for 6 to 10 years, $3.8 \%$ for 11 to 15 years, $3.8 \%$ for 16 to 20 years and the least being $0.9 \%$ of them that have been customers with the airline for over 21 years.

Table 1. Sample Characteristics

\begin{tabular}{llcc}
\hline & & Frequency & Percent \\
\hline Age Below & Below 25 Yrs & 104 & 16.4 \\
& $26-30$ Yrs & 190 & 30 \\
& $31-35$ Yrs & 130 & 20.5 \\
& 36-40 Yrs & 94 & 14.8 \\
& Above 40 Yrs & 116 & 18.3 \\
Tender & Total & 634 & 100 \\
& Male & 375 & 59.1 \\
Nationality & Female & 259 & 40.8 \\
& Total & 634 & 100 \\
& African & 339 & 53.5 \\
& Asian & 147 & 23.2 \\
& European & 95 & 15 \\
Years As Airline Customer & Australian & 53 & 8.4 \\
& Total & 634 & 100 \\
& $1-5$ Yrs & 464 & 73.2 \\
& 6-10 Yrs & 116 & 18.3 \\
& $11-15$ Years & 24 & 3.8 \\
& $16-20$ Years & 24 & 3.8 \\
& 21 Years And Above & 6 & 0.9 \\
& Total & 634 & 100 \\
\hline
\end{tabular}

\subsection{Descriptive}

Findings on tangibility summed up to a mean of 3.8459 , standard deviation 0.63601 , skewness -0.39 and kurtosis -0.495 . On the other hand the Cronbach value of 0.825 is higher than 0.70 indicating that the gathered data on tangibility are reliable as they have a relatively high internal consistency and can be generalized to reflect opinions of all respondents with regard to the study problem. The results on reliability summed up to a mean of 3.727 , standard deviation of 0.75007 , skewness -0.483 and 
Kurtosis 1. 917. In general, results on responsiveness summed up to a mean of 3.9185, standard deviation 0.64339 , skewness $-0-.132$ and kurtosis 2.007 . The Cronbach alpha value (0.826) is above 0.7 indicating that the results on responsiveness are reliable as they have high internal consistency thus can be generalized to reflect opinions of all respondents about the study problem The findings on assurance summed up to a mean of 4.0831, standard deviation 0.84288 , skewness 3.161 and kurtosis 20.407. The Cronbach's Alpha value (0.91) is more than 0.7 an indication of high internal consistency hence the results can be generalized to reflect opinions of all respondents about the study problem. The results on empathy summed up to a mean of 3.6494, standard deviation 0.78148, skewness 0.994 and kurtosis 4.296. The Cronbach's Alpha value (0.921) is more than 0.7 an indication of high internal consistency hence the results on empathy can be generalized to reflect opinions of all respondents about the study problem. Results on customer loyalty summed up to a mean of 3.9065, standard deviation 0.59503 , skewness -0.352 and kurtosis -0.632 . The Cronbach alpha value of 0.882 is above 0.7 meaning that there is high internal consistency hence the results on customer loyalty can be generalized to

Table 2. Descriptive Statistics of Scales

\begin{tabular}{|l|c|c|c|c|c|c|}
\hline & Mean & $\begin{array}{c}\text { Std. } \\
\text { Deviation }\end{array}$ & Skewness & Kurtosis & $\begin{array}{c}\text { Cronbach's } \\
\text { Alpha }\end{array}$ & $\begin{array}{c}\text { N of } \\
\text { Items }\end{array}$ \\
\hline $\begin{array}{l}\text { Customer } \\
\text { Loyalty }\end{array}$ & 3.9065 & 0.59503 & -0.352 & -0.632 & 0.881 & 10 \\
\hline Tangibility & 3.8459 & 0.63601 & -0.39 & -0.495 & 0.825 & 10 \\
\hline Reliability & 3.727 & 0.75007 & -0.483 & 1.917 & 0.87 & 10 \\
\hline Responsiveness & 3.9185 & 0.64339 & -0.132 & 2.007 & 0.826 & 10 \\
\hline Assurance & 4.0831 & 0.84288 & 3.161 & 0.407 & 0.91 & 10 \\
\hline Empathy & 3.6494 & 0.78148 & 0.994 & 4.296 & 0.906 & 10 \\
\hline
\end{tabular}

\subsection{Factor analysis}

Factors with factor loadings of above 0.5 are excellent and should be retained for further data analysis. Additionally, the first factor for $26.33 \%$ of the total variance, second factor accounted for $48.712 \%$ of the total variance and the third factor accounted for 65.584 of the total variance. Sampling adequacy was tested using the Kaiser- Meyer- Olkin Measure (KMO measure) of sampling adequacy. As evidenced in table 2, KMO was greater than 0.5, and Bartlett's Test was significant. To sum up, the 
first factor accounted for $47.895 \%$ of the total variance and the second factor accounted for $61.818 \%$ of the total variance. The Kaiser-Meyer-Olkin Measure value (0.913) was above 0.5 hence acceptable. Also, the Bartlett's Test was significant.

Factors with factor loadings of above 0.5 are excellent and should be retained for further data analysis. the first factor accounted for $34.689 \%$ of the total variance and the second factor $64.758 \%$ of the total variance. Sampling adequacy was tested using the Kaiser- Meyer- Olkin Measure (KMO measure) of sampling adequacy. As evidenced in table 4.17, $\mathrm{KMO}$ was greater than 0.5, and Bartlett's Test was significant.

Factor analysis was conducted in order to make sure that the items belong to the same construct (Wibowo, 2008). first factor accounted for $32.505 \%$ of the total variance and the second factor $63.836 \%$ of the total variance. The KMO Measure is an index for comparing the magnitude of the observed correlation coefficients to the magnitude of the partial correlation coefficients. As shown in table 4.18, KMO was greater than 0.5 , and Bartlett's Test was significant.

Factor analysis for customer loyalty was conducted to ensure that all of the constructs used are valid and reliable before proceeding for further analysis. The study requested that all loading less than 0.5 be suppressed in the output, hence providing blank spaces for many of the loadings. the first factor accounted for $41.608 \%$ of the total variance and the second factor $62.083 \%$ of the total variance. Sampling adequacy was tested using the Kaiser- Meyer- Olkin Measure (KMO measure) of sampling adequacy. As evidenced in table 4.21, KMO was greater than 0.5, and Bartlett's Test was significant.

Table 3. Factor analysis

\begin{tabular}{|l|c|c|c|}
\hline & Loadings & \% of Variance & KMO \\
\hline Tangibility 1 & 0.689 & 26.333 & 0.78 \\
\hline Tangibility 2 & 0.658 & 22.379 & \\
\hline Tangibili9ty 3 & 0.838 & 16.872 & \\
\hline Reliability 1 & 0.652 & 47.895 & 0.913 \\
\hline Reliability 2 & 0.767 & 13.923 & \\
\hline Responsiveness 1 & 0.655 & 31.119 & 0.846 \\
\hline Responsiveness 2 & 0.823 & 26.59 & \\
\hline Assurance 1 & 0.555 & 34.689 & 0.908 \\
\hline assurance 2 & 0.773 & 30.069 & \\
\hline Empathy 1 & 0.777 & 32.505 & 0.886 \\
\hline empathy2 & 0.859 & 31.331 & \\
\hline Customer Loyalty 1 & 0.778 & 41.608 & 0.891 \\
\hline
\end{tabular}


Journal of Business Management and Economic Research (JOBMER), vol.3, issue.10, pp.1-19

\begin{tabular}{|l|l|l|l|}
\hline customer Loyalty 2 & 0.817 & 20.475 & \\
\hline
\end{tabular}

\subsection{Assumptions of Regressions}

Further, to test the normality distribution the study examined the Skewness and kurtosis values. Skewness is used to measure the symmetry of a distribution while kurtosis is used to measure the peakness or flatness of a distribution (Tabachnick and Fidell, 2007). Based on the results, the values of Skewness and kurtosis revealed that the data was normally distributed where the values were well below the threshold of $+/-10$. Kolmogorov-Smirnov was used (Shapiro and Wilk,1965) which were calculated for each variable. The results from these tests revealed $\backslash$ that all the variables were not significant, which meets the assumptions of normality. Results shows that testing at the 0.05 level of significance; none of the Levenne statistics was significant. The assumption of homoscedasticity was not violated. The VIF values in table 3 were less than four meaning that there was no multicollinearity.

\subsection{Hypothesis testing}

Table 3 illustrates Pearson correlation results of the study dependent and independent variables to assess the association of the variables. Findings revealed that tangibility was positively and significantly correlated with customer loyalty $(r=0.507$, $@<0.01)$. Further, reliability was positively and significantly correlated to customer loyalty $(r=0.596, Q<0.01)$. Likewise, responsiveness was positively correlated with customer loyalty $(\mathrm{r}=0.538, \mathrm{Q}<0.01)$. Also, assurance was indicated to positively relate with customer loyalty $(\mathrm{r}=0.481, \mathrm{Q}<0.01)$. This implies that tangibility, reliability, responsiveness, assurance, empathy, customer satisfaction and cultural orientation are expected to influence customer loyalty.

The first hypothesis of the study stated that there is no significant effect of tangibility on customer loyalty in selected African Airlines. However, findings in table 4.28 showed that tangibility had coefficients of estimate which was significant basing on $\beta_{1}=0.14$ (p-value $=0.000$ which is less than $\alpha$ $=0.05)$ thus we reject the null hypothesis and conclude that tangibility has a significant effect on customer loyalty in selected African Airlines. tangibles as a dimension of service quality exhibited a positive and significant effect on customer loyalty in selected African airlines. In tally with the results, Tax \& Brown, (2012) established that both tangibles and intangible aspects of service quality were 
Journal of Business Management and Economic Research (JOBMER), vol.3, issue.10, pp.1-19

key in enhancing customer loyalty and influencing the overall organization performance. The results also corroborate that of Zineldin (2005) which found out that by combining both tangible and intangible attributes of premium quality in products and services provided by airlines, they have a high propensity to create a strong and long-term relationship with their customers. Moreover, a study conducted in the Telecommunication industry in Ghana by Idrissu (2011) revealed that tangibles, responsiveness and reliability were directly related with customer loyalty. As well, Kheng et al. (2010) established that empathy had the highest positive association while assurance had least association with customer loyalty. However, Kheng et al., (2010) study on airline customers in Malaysia found that among the five dimensions used in the SERVQUAL model, tangibles had no significant influence on consumer loyalty.

The second hypothesis stated that reliability has no significant effect on customer loyalty in selected African Airlines. Nonetheless, the study findings showed that reliability has a positive and significant effect on customer loyalty in selected African Airlines basing on $\beta_{2}=0.204$ ( $p$-value $=0.000$ which is less than $\alpha=0.05$ ) implying reliability has a significant effect on customer loyalty. In line with the results, Jamal and Anatassiadou (2007) study on airline customers in Greece showed that reliability, tangibility and empathy are positively related to consumer loyalty. In a similar vein, Arasli et al., (2005) reported that assurance, reliability, empathy and tangibles dimensions of service quality were predictors of consumer loyalty. The results are also in conformity with that of Siddiqui, (2011) that asserted that service quality such as reliability, empathy and service quality were found to be positively correlated with customer loyalty. Besides, the findings are in support of a study by Kheng et al., (2010) carried out a study on airline customers in Malaysia that found out that reliability has a positive association with customer loyalty.

The third hypothesis of the study stated that responsiveness has no significant effect on customer loyalty in selected African Airlines. However, the study findings showed that responsiveness had coefficients of estimate which was significant basing on $\beta_{3}=0.122$ (p-value $=0.01$ which is less than $\alpha$ $=0.05$ ) implying that we reject the null hypothesis stating that responsiveness has no significant effect on customer loyalty in selected African Airlines. In corroboration with the above findings, a study conducted by Al-Rousan and Mohamed (2010) in the hotel industry in Jordon found out that empathy, reliability, responsiveness, tangibles and assurance significantly forecast customer loyalty. As well, Arasli et al., (2005) reported that tangibles, empathy and responsiveness were significant 
predictors of customer loyalty. In addition, Liang (2008) study found out that service quality has a positive influence on consumer loyalty.

The fourth hypothesis of the study stated that assurance has no significant effect on customer loyalty in selected African Airlines. This was however refuted since assurance has a positive and significant effect on customer loyalty in selected African Airlines basing on $\beta_{4}=0.093$ (p-value $=0.027$ which is less than $\alpha=0.05$ ) thus we fail to accept the hypothesis and conclude that assurance has a significant effect on customer loyalty in selected African Airlines. In tally with the results, Poku et al. (2014) elucidate that assurance as one of the five constructs of the SERVQUAL model strongly associates with customer loyalty. In a similar vein, a study conducted by Kheng et al., (2010) among airline customers in Malaysia revealed that assurance has a positive and significant association with customer loyalty. In addition, the relationship between customer satisfaction and customer loyalty might be nonlinear. Heskett et al. (2008) suggested that customer loyalty should improve dramatically when custom- er satisfaction overcome a certain level. In sum, the dominant proposition is that satisfaction is an essential necessary parts to achieve customer loyalty. In addition, as it presented here in early part, service quality is assumed to be an antecedent of customer satisfaction. Therefore, it can be interesting to test the relationship between service quality and customer loyalty with customer satisfaction as the mediator of this relationship.

The fifth hypothesis stated that the empathy has no significant effect of reliability on customer loyalty in selected African Airlines. Nonetheless, the study findings showed that empathy has a positive and significant effect on customer loyalty in selected African Airlines basing on $\beta_{5}=0.284$ ( $p$-value $=0.000$ which is less than $\alpha=0.05$ ) implying empathy has a significant effect on customer loyalty. Empathy as a key dimension of service quality has been found to have a significant positive association with customer loyalty. The results corroborate with that of Iglesias and Guillén, (2004) which found out that there is a positive and significant relationship between empathy and customer loyalty. Akin to the above findings, Ndubisi (2006) echoes that customer satisfaction and in turn loyalty can be achieved by offering personalized, flexible and adjustable services that are in line with the expectations of the customers. The results suggest that empathy impacts positively on customer loyalty. Furthermore, Wieseke et al. (2012) established that consumers that were treated

To sum up, findings from the table revealed that $47.2 \%$ variation of customer loyalty is predicted by tangibility, reliability, responsiveness, assurance and empathy $\left(R^{2}=0.472\right)$. Their joint prediction was 
significant as shown by $\mathrm{F}$ value of 112.133 , $\mathrm{Q}<0.05$. Furthermore, the VIF values were less than 4 indicating the absence of multi-collinearity and thus the variation contributed by each of the independent variables was significant.

Table4. Direct effect

\begin{tabular}{|c|c|c|c|c|c|c|c|c|}
\hline & \multicolumn{2}{|c|}{$\begin{array}{l}\text { Unstandardized } \\
\text { Coefficients }\end{array}$} & \multicolumn{3}{|c|}{$\begin{array}{c}\text { Standardized } \\
\text { Coefficients }\end{array}$} & \multirow{2}{*}{$\begin{array}{l}\text { correlation } \\
\text { zero order }\end{array}$} & \multicolumn{2}{|c|}{$\begin{array}{c}\text { Collinearity } \\
\text { Statistics }\end{array}$} \\
\hline & B & $\begin{array}{l}\text { Std. } \\
\text { Error }\end{array}$ & Beta & $\mathbf{t}$ & Sig. & & Tolerance & VIF \\
\hline (Constant) & 1.129 & 0.13 & & 8.665 & 0.00 & & & \\
\hline Tangibility & 0.13 & 0.036 & 0.14 & 3.648 & 0.00 & .507 & 0.574 & 1.742 \\
\hline Reliability & 0.167 & 0.038 & 0.204 & 4.377 & 0.00 & .596 & 0.388 & 2.578 \\
\hline Responsiveness & 0.11 & 0.042 & 0.122 & 2.591 & 0.01 & .538 & 0.377 & 2.656 \\
\hline Assurance & 0.09 & 0.041 & 0.093 & 2.21 & 0.027 & .481 & 0.474 & 2.109 \\
\hline Empathy & 0.246 & 0.034 & 0.284 & 7.202 & 0.00 & .595 & 0.543 & 1.842 \\
\hline$R$ & $0.687 a$ & & & & & & & \\
\hline R Square & 0.472 & & & & & & & \\
\hline Adjusted $R$ & & & & & & & & \\
\hline Square & 0.467 & & & & & & & \\
\hline Durbin-Watson & 0.732 & & & & & & & \\
\hline$F$ & 112.133 & & & & & & & \\
\hline Sig. & $0.000 b$ & & & & & & & \\
\hline
\end{tabular}

a Dependent Variable: Customer Loyalty 
Journal of Business Management and Economic Research (JOBMER), vol.3, issue.10, pp.1-19

\section{Conclusion and Recommendations}

Based on the findings in chapter four, results on reliability revealed that the customers trust the services offered by the airline because the airline staff keep the transactions correctly. Also, the airline correctly performs a service from the very first time without failures or errors. Moreover, the airline staff are dependable in handling customers' issue and the passengers are informed about when services are performed. Besides, passengers are compensated sufficiently by the airline for any damages arising from service disruption in the shortest time possible. The implication is that the level of loyalty to a particular airline may remain low if a gap is left in terms of the level of empathy they are accorded with the airline. In this regard, empathy is effective in creating an emotional relationship with the airline passengers hence providing the passengers with a touch of importance and a sense of belonging. The end result is customer loyalty since the customers are treated emphatically.

The study has established that the tangible dimension of service quality is of essence in the airline industry because it sets up a clear transmission of knowledge through information materials such as brochures, provision of top notch service (high quality foods and drinks served inflight) and the physical layout of equipment which build customer relationship by delivering superior value over competitors to the target customers thus contributing to customer loyalty. In addition, assurance enables the airline staff to inspire trust and confidence from the passengers thus leading to customer loyalty. The implication is that the airline staffs deliver services to customers that is believable and can be trusted. Consequently, the passengers recommend their family and friends to the airline. Most importantly, the airline staff are well trained thus they have the skills and knowledge to effectively enhance customer loyalty within the selected African airlines.

Finally, it can be said that whenever customers' requests are quickly responded to and are assisted in the shortest time possible, the implication is that they will be satisfied with the service delivery and become loyal customers. As well, convenient operating hours together with commitment to on time services are key in enhancing customer loyalty.

It is therefore paramount for the airline to deliver its services at promised times and handling customer's complaints effectively. Particularly, there is need for the airline staff to have a "do-it-rightfirst" attitude". The airline staffs need to be dependable in handling customers' issue and keep them 
in the know in regards to the services performed. As well, passengers need to be compensated for any damages resulting from service disruption.

it is important for airline staff to treat passengers with great respect, giving individual attention to passengers, serving passengers based on their specific needs and treating them in a friendly manner. Additionally, the complain process needs to be convenient to use and the feedback should be prompt. These factors need to be focused on in order to enhance customer loyalty.

Moreover, the airline staffs need to be neat since it affects the ways in which customers respond. Precisely, professional appearance among the employees is effective in attracting and maintaining customers. Further, it is crucial for the airline to adopt modern equipment and have information materials that are visually appealing.. Also, they need to be polite, courteous and provide information that is clear. Besides, they have to be well trained so that they can offer quality service that will enable the airline to have a competitive advantage. The sample was drawn from only drawn from 9 Airlines in Africa; thus, this study may be limited in its generalizability of the findings to the selected African airlines. So, future research should have to draw sample of respondents on more number of airlines for the sake of generalizing the results of the study.

\section{References}

AbedinZ(2015).Service Quality Level and the Perception of Customers: A Study on Nijhoom Tours A $5^{*}$ Rated Travel and Tourism Company in Bangladesh. British Journal of Marketing Studies, Vol.3, No.3.Pp.80-100.

Agyei, P. M., \& Kilika, J. M. (2013).Relationship between service quality and customer loyalty in the Kenyan telecommunication service industry. European Journal of Business and Management, 5(23), 26-36.

Ajzen, I. (2001) Nature and operations of attitudes. Annual Review of Psychology.vol. 5227-58.

Ajzen, I., \&Fishbein, M. (1975). Attitude-behavior relations: A theoretical analysis and review of empirical research. Psychological Bulletin, 84, 888-918

Al-Marri, K., Ahmed, A.M.M.B. and Zairi, M., (2007). Excellence in service: an empirical study of the UAE banking sector. International Journal of Quality and Reliability Management, 24(2), 164-176

Al-Rousan, M. Ramzi, Badaruddin Mohamed (2010), “Customer Loyalty and the Impacts of Service Quality: The Case of Five Star Hotels in Jordan", International Journal of Human and Social Sciences 5:13 2010 
Journal of Business Management and Economic Research (JOBMER), vol.3, issue.10, pp.1-19

Arasli, Q. H. (2005). Relationship between Service Features and Customer Loyalty in Banking sector: An exploratory Study: International Journal of Islamic and Middle Eastern Finance and Management. 1(3),191-209.

Bielen, F., \& Demoulin, N. (2007). Waiting time influence on the satisfaction-loyalty relationship in services. Managing Service Quality, 17(2), 174-193

Brady, M.K. and Cronin, J.J. Jr (2002), "Some new thoughts on conceptualizing perceived service quality: a hierarchical approach", Journal of Marketing, Vol. 65, pp. 34-49

Corstjens, Marcel and Rajiv Lal (2000), "Building Store Loyalty Through Store Brands," Journal of

Marketing Research, 37(August), 281-91.

Cronin, J.J. Jr and Taylor, S.A. (2000), "Measuring service quality: a re-examination and extension", Journal of Marketing, Vol. 56, pp. 55-68

Ehigie, B. O. (2006), "Correlates of customer loyalty to their bank: a case study in Nigeria" International Journal of Bank Marketing, 24(7), 494-508.

Ganguli, Sh. \& Roy, S. (2011). Generic technology-based service quality dimensions in banking Impact on customer satisfaction and loyalty. International Journal of Bank Marketing, 22(2), 168189.

Gitomer, J. (1998). Customer Satisfaction is Worthless, Customer Loyalty Is Priceless. Texas: Bard Press.

Gounaris, S. and Stathakopoulos, V. (2003), "Antecedents and consequences of brand loyalty: an empirical study", Journal of Brand Management, Vol. 11 No. 4, pp. 283-306.

Hassan, M. U., Malik, A. A., Imran, M., Amna, H., \& Abbas, J. (2013).Relationships Vamong customers' perceived service quality, satisfaction and loyalty in the retail banking sector of Pakistan. World Applied Sciences Journal,24(8), 1020-1030. doi:10.5829/idosi.wasj.2013.24.08.13254

Heskett, J. L., Jones, T. O., Loveman, G. W., Sasser Jr., W. E., \& Schlesinger, L. A. (2008).Putting the service-profit chain to work. Harvard Business Review, 86(7-8), 118-129+162

Iglesias, M. P., \&Guillen, M. J. Y. (2004). Perceived quality and price: their impact on the satisfaction of restaurant customers. International Journal of Contemporary Hospitality Management, 16(6), 373-379

Jabnoun, N., \& Al-Tamimi, H. (2003). Measuring perceived service quality at UAE Commercial Banks.InternationalJournalofQuality\&ReliabilityManagement,20(4),458472.http://dx.doi.org/10.1108/02656710310468614

Jamal, A. and Ananstasiadou, K. (2007), "Investigating the effects of service quality dimensions and expertise on loyalty", European Journal of Marketing, Vol. 43 Nos 3/4, pp. 398-420.

Karatepe, O. M, (2011), "Service quality, customer satisfaction and loyalty: the moderating role of gender", Journal of Business Economics \& Management, Vol.12,No.2: 278 - 300

Ladhari, R., Ladhari, I. and Morales, M. (2011), “Bank service quality: comparing Canadian and Tunisian customer perceptions", International Journal of Bank Marketing, Vol. 29 No. 3,pp. 224-246. 
Journal of Business Management and Economic Research (JOBMER), vol.3, issue.10, pp.1-19

Liang, C.J., Wang, W.H. and Farquhar, J.D. (2008), "The influence of customer perceptions on financial services", International Journal of Bank Marketing, Vol. 27 No. 2, pp. 129-149

Muyeed, M. A. (2012). Customer Perception on Service Quality in Retail Banking inDeveloping Countries-A Case Study. International Journal of Marketing Studies, 4(1),116-122

Ndubisi, N.O., Wah, C.K. (2006) "Factorial and discriminant analyses of the underpinning of relationship marketing and customer satisfaction", International Journal of bank marketing, 23(7): 542-557

Parasuraman, A., Zeithaml, V.A. and Berry, L.L. (2005),“A conceptual model of service quality and its implications for future research", Journal of Marketing, Vol. 49,pp. 41-50

Schiffman L.G., Kanuk L.L., Hansen H., (2008), “Consumer Behaviour" A European Outlook, The Consumer as an Individual, Self and Self-Image, Pearson Education, p.67-281

Swar, B. N., \&Sahoo, P. K. (2012).Public, Private, and Foreign Banks. Journal Of Indian Management, 9(3), 43-51

Tax, S. S., \& Brown, S. W. (2012). Recovering and learning from service failure. MITSloan Management Review, 40(1), 75-88

Vogel V., Evanschitzky H., Ramaseshan B., Journal of Marketing, November 2008., Vol. 10, p.98-108

Wieseke, J., Geigenmüller, A., \& Kraus, F. (2012).On the role of empathy in customer-employee interactions. Journal of Service Research, 15(3), 316-331.

Zineldin, M., Philipson, S. (2005) " Kotler and Borden are not dead: myth of relationship marketing and truth of the 4Ps" Journal of Consumer Marketing, 24(4): 229-241 